\title{
JUURNAL.RU
}

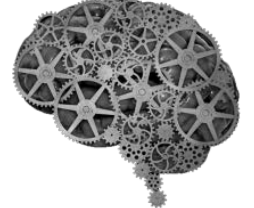

COMPANY GROUP "INTELLEKT"

Каипов Я.З., Шамситдинов В.И. Бамкирский НИИ сельского хозяйства Уфа, Россия

doi: 10.18411/lj2016-9-1-06

idsp 000001: lj2016-18-1-06

\section{Создание самовозобновляемых культурных сенокосов в степной зоне Южного Урала}

Сено является одним из важнейших видов кормов. В среднем по России сельскохозяйственные животные получают с сеном примерно 40-50 \% кормовых единиц и 50-70 \% переваримого протеина, потребляемого ими за стойловый период. Объемы заготовки в настоящее время сена недостаточно обеспечивают потребности животноводства. Это связано с низкой урожайностью природных кормовых угодий и слабой отзывчивостью их травостоев на улучшающие мероприятия. Культурные сенокосы создаются на угодьях с более плодородными почвами, с использованием сортовых трав. Однако со временем культурные травы снижают свою продуктивность и начинают по этому показателю приближаться к естественным травостоям. В засушливых условиях степной зоны уже на 5-6-й год сеяные травы резко снижают урожайность сена. Их перепашка и пересев требуют большие затраты. Предлагается значительно более дешевая технология продлевания продуктивного долголетия культурных сенокосов и пастбищ для умеренно увлажненных природных зон [1].

Процессы самовозобновления сеяных травостоев при улучшающих мероприятиях в засушливой степной зоне мало исследованы [2].

Мы поставили целью исследовать закономерности изменения старовозрастных травостоев под действием агротехнических приемов и разработать технологию создания долголетних самовозобновляемых травостоев культурных сенокосов для степной зоны Южного Урала. 
Полевые опыты были проведены в Баймакском научном подразделении Башкирского НИИ сельского хозяйства, относящимся к степной зоне Южного Урала с характерными для этого региона условиями. Рельеф равнинный, почвы представлены черноземом обыкновенным тяжелосуглинистым. Мощность гумусового горизонта в пределах 40-48 см, содержание гумуса в слое 0-20 см в среднем 6,8-7,5\%. Обеспеченность подвижным фосфором средняя, обменным калием - повышенная. Схема опыта включала 4 варианта обработки почвы (дернины): без обработки, дискование на глубину 8-10 см одним проходом дискатора БДМ-6-4 летом после первого укоса, дискование с подсевом люцерны, дискование с подсевом эспарцета; 5 вариантов удобрения: без удобрения, P60 K45 - фон, фон + N45, фон + N60, фон + N90. Фосфорнокалийные удобрения вносили осенью, азотные - рано весной после таяния снега.

Климат засушливый, среднегодовое количество осадков 330 мм, в т.ч за период вегетации трав (май-сентябрь) - 194 мм. Обеспеченность теплом за годы исследований (2011-2016 гг.) была значительно выше среднемноголетних значений. Средняя температура воздуха за вегетационный период составила 16,4 0 при среднемноголетней 14,90 С. Анализируемые годы в среднем оказались более засушливыми, со среднегодовой суммой осадков 169 мм.

Четыре года из шести - 2011, 2012, 2014 и 2016 гг. - были засушливыми, с обеспеченностью осадками менее 88 \%. В том числе два года - 2012 и 2014 были сильнозасушливыми, когда за вегетационный период выпали всего 27-71 \% осадков от нормы. В благоприятные годы по осадкам (2013 и 2015), в вариантах с применением приемов улучшения, старовозрастные травостои обеспечивали сбор СВ (сухого вещества) надземной кормовой массы в интервале 26-42 ц/га. Этот показатель близок к расчетной урожайности СВ молодых травостоев сеяных многолетних трав в Зауральской степи, составляющей 40 ц/га. В острозасушливые годы урожайность снизилась до 8-9 ц/га.

Среднемноголетняя урожайность СВ укосной массы в контроле без обработки дернины и удобрений составила 12,7 ц/га (табл. ). Под действием приемов улучшения выход СВ урожая увеличилась до $15,1-22,5$ ц/га, или в 1,21,8 раза относительно контроля. 
Среднемноголетняя продуктивность старовозрастного улучшаемого

сенокоса под влиянием удобрений и обработки дернины (2011-2016 г2.)

\begin{tabular}{|c|c|c|c|c|c|c|}
\hline \multirow{2}{*}{$\begin{array}{c}\text { Обработка } \\
\text { почвы }\end{array}$} & \multirow[b]{2}{*}{ Удобрение } & \multirow{2}{*}{$\begin{array}{c}\text { Сбор } \\
\text { СВ, ц/га }\end{array}$} & \multicolumn{4}{|c|}{ Разницы по факторам } \\
\hline & & & Дискова-ние & Удобрение & $\begin{array}{l}\text { Дискова-ние } \\
+ \text { удобрение }\end{array}$ & $\begin{array}{c}\text { Дискова-ние } \\
+ \text { подсев }\end{array}$ \\
\hline \multirow{5}{*}{$\begin{array}{c}\text { Без } \\
\text { обработки }\end{array}$} & $\begin{array}{c}\text { Без удобрения } \\
\text { (контроль) }\end{array}$ & 12,7 & - & 0 & & \\
\hline & PK - фон & 15,2 & 一 & 2,5 & & \\
\hline & $\Phi \mathrm{OH}+\mathrm{N}_{45}$ & 17,9 & - & 5,1 & & \\
\hline & $\Phi \mathrm{OH}+\mathrm{N}_{60}$ & 20,3 & - & 7,6 & & \\
\hline & $\Phi \mathrm{OH}+\mathrm{N}_{90}$ & 22,3 & - & 9,6 & & \\
\hline \multirow{5}{*}{ Дискова-ние } & Без удобрения & 15,1 & 2,3 & - & 0 & \\
\hline & РК - фон & 17,5 & 2,3 & 2,5 & 4,8 & \\
\hline & $\Phi$ oH $+\mathrm{N}_{45}$ & 21,3 & 3,4 & 6,2 & 8,6 & \\
\hline & $\Phi \mathrm{OH}+\mathrm{N}_{60}$ & 22,5 & 2,2 & 7,4 & 9,7 & \\
\hline & $\Phi \mathrm{OH}+\mathrm{N}_{90}$ & 21,9 & $-0,4$ & 6,8 & 9,1 & \\
\hline \multirow{3}{*}{$\begin{array}{c}\text { Дискова-ние } \\
+ \\
\text { подсев } \\
\text { люцерны } \\
\end{array}$} & Без удобрения & 18,0 & - & & & 5,3 \\
\hline & PK - фон & 19,5 & - & & & 6,7 \\
\hline & Фон $+\mathrm{N}_{45}$ & 20,2 & - & & & 7,4 \\
\hline \multirow{3}{*}{$\begin{array}{c}\text { Дискова-ние } \\
+ \\
\text { подсев } \\
\text { эспарцета } \\
\end{array}$} & Без удобрения & 17,4 & - & & & 4,7 \\
\hline & PK - фон & 20,0 & - & & & 7,3 \\
\hline & $\Phi \mathrm{OH}+\mathrm{N}_{45}$ & 22,2 & - & & & 9,5 \\
\hline
\end{tabular}

Наибольшее действие на состояние травостоя сеяного сенокоса оказывали удобрения. В среднем за 2011-2015 гг. прибавки от удобрений на фоне без обработки дернины составили от 2,5 до 9,6 ц с 1 га. Наибольшая средняя прибавка урожайности улучшаемого травостоя достигнута на фоне фосфорнокалийного удобрения, дополненного внесением максимальной в опыте дозы азота 90 кг/га. Средняя прибавка урожайности от дискования составляет от 2,1 до 3,4 ц/га. Такая прибавка урожайности является существенной. С учетом меньших затрат на проведение этого механического приема улучшения по сравнению с применением дорогостоящих удобрений, дискование можно рекомендовать как наиболее доступный прием увеличения продуктивного долголетия многолетних травостоев.

По положительному влиянию на продуктивное долголетие травостоев многолетних трав совместное применение дискования и удобрений превосходило влияния на этот показатель одних минеральных удобрений. Прибавки по этому комплексному фактору относительно контролю составляли от 4,8 до 9,7 ц/га СВ урожая.

В среднем за шестилетие (2011-2016 гг.), подсев бобовых трав в продискованную дернину обеспечил значительное повышение урожайности ( на 2,0 -2,9 ц/га, или на 11-20 \%) старовозрастного травостоя по отношению к фону с одним дискованием только на фонах без удобрения и с внесением Р60 
К45. А в вариантах «Фон (Р60 К45) + азотные удобрения» подсев бобовых трав не обеспечил прибавку по отношению к уровню урожайности при дисковании без подсева. Если учесть, что подсев трав в улучшаемый травостой является относительно дорогостоящим агротехническим мероприятием и не обеспечивает достаточную прибавку урожайности, этот прием повышения продуктивного долголетия не может быть рекомендован производству в условиях засушливого степного Зауралья Республики Башкортостан.

Следовательно, в условиях засушливой степи Зауралья Республики Башкортостан наиболее действенными приемами повышения продуктивного долголетия сеяных травостоев многолетних трав является применение удобрений а также совместное применение дискования и удобрения. Фосфорнокалийные удобрения необходимо вносить в дозах 60 и 45 кг/га д.в. В дополнение к ним рекомендуем применять азотные удобрения от 45 до 90 кг/га д.в. в зависимости от увлажнения года. В засушливые годы дозы азота свыше 45 кг/га не приводят к росту урожайности и поэтому неэффективны. До сих пор преобладало мнение о том, что эффективное омолаживающее действие удобрений проявляется только в лесостепной и горно-лесной зонах с достаточным увлажнением [3].

Эффективным приемом повышения продуктивного долголетия является также дискование травостоя многолетних трав. Хотя этот прием обеспечивает значительно меньшие прибавки, чем удобрения, но благодаря меньшей затратности может успешно применяться в хозяйствах с ограниченными ресурсами. 


\section{Литература:}

1. Трофимова Л.С., Кулаков В.А., Новиков С.А. Продуктивный и средообразующий потенциал луговых агрофитоценозов и пути его повышения // Кормопроизводство. - № 9. - 2008. - С. 17-19.

2. Мазитов Н.К., Хабибуллин Ф.Х. Шайтанов О.Л. и др. Резервы повышения продуктивности естественных и сеяных сенокосов и пастбищ в засушливых условиях // Достижения науки и техники АПК. - № 7, 2011. C. 73-75.

3. Лепкович И.Л. Современное луговодство. - СПб: Профи-Информ, 2008. C. $75,231-237$. 